\title{
Water quality condition of Sani river as source of drinking water of PDAM Tirta Bening in Pati Regency
}

\author{
Evta Rina Mailisa*, Bambang Yulianto, and Budi Warsito \\ Master Program of Environmental Sciences, School of Post-Graduate, Diponegoro University, \\ Semarang - Indonesia
}

\begin{abstract}
Sani river is one of the rivers in Pati Regency, provided as the drinking water source by PDAM Tirta Bening. The people's activities inhabit along the Sani river affect its water quality. The purpose of this study was 1) analyzed the quality of the Sani river water, and 2) evaluated the status of the Sani river water quality. The data used was the 2018 Sani river water quality data obtained from the Environmental Services of Pati Regency. The study's location was represented by selected three monitoring points, i.e., upstream, middle, and downstream areas of the Sani river, such as the Seloromo reservoir, Sidokerto village, and Gilis hamlet. For knowing the river water quality level, it was necessary to compare the river water quality data with the Indonesia Government Regulation (PP) No. 82/2001. The Sani river water quality status was analyzed using the pollution index method according to the Decree of the Minister of Environment No. 115/2003. In conclusion, the Sani river water quality status in such the- study site was classified as slightly polluted and moderate polluted.
\end{abstract}

Keywords : Water quality, pollution, index, water surface, Sani river

\section{Introduction}

Water is included in one of the natural resources needed in daily life [1]. Clean water is one of the essential components required by humans in life. Related to water is one of the Sustainable Development Goals' objectives or commonly abbreviated as SDGs [2]. Clean water can be obtained from springs in lakes, or river water. One of river water function is a source of raw water that can be processed into clean water for daily needs. In Indonesia, river water treatment is carried out by a Regional Water Company (PDAM) using a Water Treatment Installation (IPA) using physics and chemistry. The development of industry, trade, public markets, hospitals and increased community growth around watersheds enhances technological developments and dense settlements further increase the intensity of wastewater that brings pollutants to watersheds.

\footnotetext{
* Corresponding author: evtarina@gmail.com
} 
The river's choice as an indicator of environmental quality is because the river has a very significant role as a source of drinking water and a source of raw water for various other needs such as agriculture, industry, and a power plant. The population growth that has increased from year to year has an impact on rising water needs to meet the needs of the population. On the other hand, this population growth also decreased water quality in raw water sources due to land use and human activities [3]. Given these conditions, it is crucial to maintain the quality and quantity of river water. Based on Government Regulation (PP) No. 82 of 2001, the Government has arranged efforts to manage water quality and control water pollution, further clarified by Regulation of the Minister of Environment No. 1 of 2010 concerning Procedures for Water Pollution Control. In the Regulation of the Minister of the Environment, the Regional Government Guidelines, especially in the regency/city, have been regulated in implementing water pollution control. The key parameters measured in the calculation of water quality index have dissolved oxygen (DO), suspended solids (TSS), biological oxygen demand (BOD), chemical oxygen demand (COD), Total Phosphate, Fecal Coli, and Total Coliform [4].

Pati Regency has a large number of rivers. Rivers in Pati Regency generally function in irrigation. Unfortunately, in the dry season, most rivers that experience drought, while in the rainy season, some rivers overflow. In the Strategic Environmental Assessment (KLHS), the revised spatial plan for Pati Regency in 2010 - 2030 states that the river water quality index in Pati Regency uses three rivers; the Sani River, Jiglong River, and Lengkowo River. The selection of Sani River as a priority to control its pollution is because the Sani River is the source of PDAM Tirta Bening. The river's condition as one of the sources of raw water in several regions of Indonesia is far above the required quality standards [5]. With the study of water quality in the Sani river, it is expected that the conditions can meet the necessary quality standards. This study aimed to analyze the water quality of the Sani River and analyze the status of the Sani River water quality.

\section{Methodology}

\section{1 Data Collection}

This review uses secondary data released from the Environmental Services of Pati Regency. The secondary data consisting of data from the Sani river water quality analysis taken in September 2018.

\section{2 Data Analysis}

The data analysis method used was descriptive. Water quality analysis was carried out by comparing the Sani river water quality data with water quality standards class II set by the Government (Government Regulation No. 82/2001). The regulation contains Water Quality Management and Water Pollution Control. Parameters having values exceeding water quality standards were analyzed for the cause.

Pollution analysis was done by calculating the water quality index value. The water quality index value is determined using the river water pollution index (PIj) method with the formula: 


$$
\mathrm{PI}_{j}=\frac{\sqrt{(\mathrm{Ci} / \mathrm{Lij})^{2} \mathrm{M}+(\mathrm{Ci} / \mathrm{Lij})^{2} \mathrm{R}}}{2}
$$

Information :

Lij : concentration of water quality parameters stated in the standard water allotment quality (j)

$\mathrm{Ci} \quad$ : concentration of water quality parameters from survey results

$\mathrm{PIj}$

(Ci/Lij)M : maximum $\mathrm{Ci} / \mathrm{Lij}$ value

$(\mathrm{Ci} / \mathrm{Lij}) \mathrm{R}$ : Average $\mathrm{Ci} / \mathrm{Lij}$ value

This method can directly connect the level of contamination with whether or not waters are used for a specific designation and with the value of certain parameters. An evaluation of the PI values based on Minister of Environment Decree No. 115/2003 is shown in the following table :

Table 1. Relationship between PI Value and water quality status

\begin{tabular}{cc}
\hline PIValue & Water quality \\
\hline $0-1,0$ & Good condition \\
$1,1-5,0$ & Slightly pollution \\
$5,0-10,0$ & Moderate polluted \\
$>10,0$ & Heavily polluted \\
\hline
\end{tabular}

The parameters and analysis methods used in this study based on The Environmental Services of Pati Regency data (2018) were :

Table 2. Parameters and analysis methods

\begin{tabular}{ll}
\hline \multicolumn{1}{c}{ Parameter } & \multicolumn{1}{c}{ Analysis Methods } \\
\hline TSS & SNI 06-6989.3-2004 \\
DO & SNI 06-6989.14-2009 \\
BOD & SNI 06-6989.72-2009 \\
COD & SNI 06-6989.2-2009 \\
Fecal Coliform & MPN \\
Coliform Total & MPN \\
\hline
\end{tabular}

\section{Result and Discussion}

Sani River is one of the rivers that flow in Pati Regency which functions as a raw water source for PDAM Tirta Bening. In the 2019 report, the number of customers served by PDAM Tirta Bening until 2019 was 34,621. Customers use PDAM water to meet water needs in the household including kitchen, bathroom, toilet, and washing clothes. Sani river water condition is directly proportional to the processing costs incurred by the PDAM Tirta Bening. The more dirty and polluted river water is, the higher the costs spent on processing raw water so that the drinking water produced can meet the Minister of Health Regulation No. 32 of 2017. Therefore, by maintaining the quality of the Sani river water so that it can at least meet the class II water quality standards according to Government Regulation Number 82/2001, it is expected to facilitate the processing of Sani River water into clean water. 
There are three monitoring locations in this study, namely locations representing the upstream, middle, and downstream areas. For more details, monitored sites are as follows :

Table 3. Sampling Location

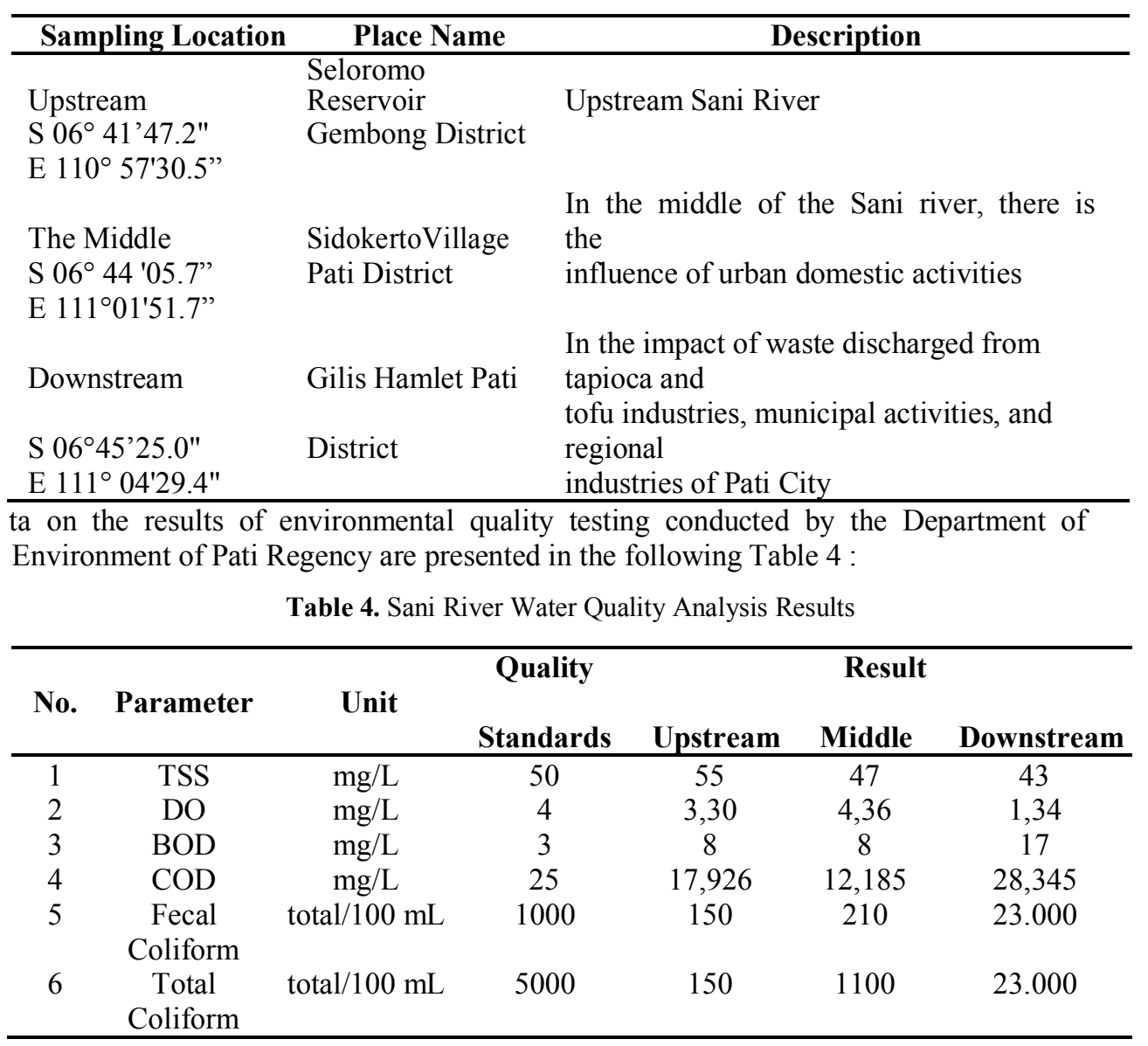

\subsection{Water Quality Analysis}

The rivers in Pati Regency have not yet determined the water quality classification, so they are still classified as group II referring to Government Regulation (PP) No. 82/2001. Water quality Category 2 can be used as a means of water recreation, freshwater fish aquaculture, livestock, water for agricultural functions, and other uses that require the same water quality as these uses. The results of the analysis for each parameter are shown as follows:

\subsubsection{Suspended residue (TSS)}

Suspended materials with a diameter of $>1 \mu \mathrm{m}$ and are retained in a millipore sieve with a pore diameter of $0.45 \mu \mathrm{m}$. TSS consists of fine sand, mud and microorganisms caused by soil erosion carried into water bodies [6]. Suspended solids are solids that cause the water's turbidity, are not dissolved, and cannot settle [7]. 


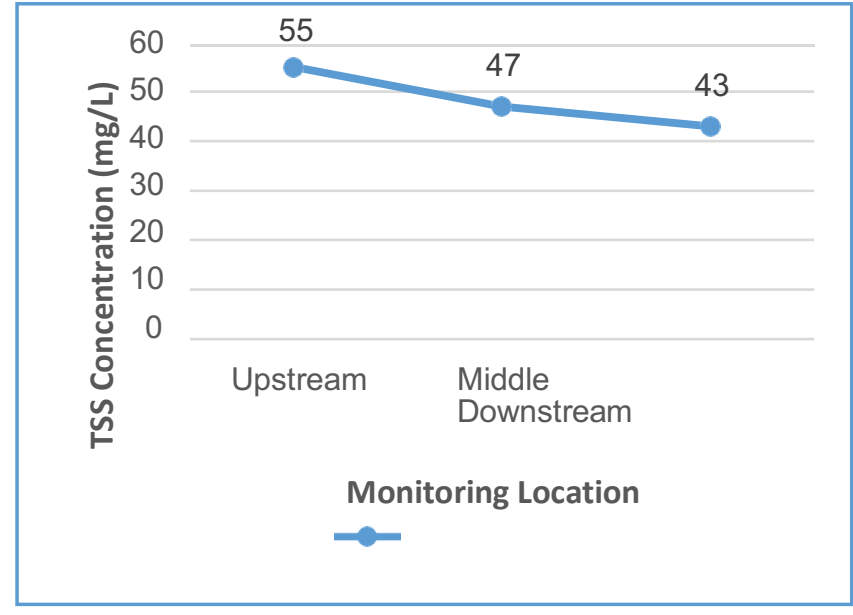

Fig. 1. Graph of TSS concentration in the monitoring location

Based on the water quality anaysis obtained, it was known that the highest concentration of TSS was discovered in the upstream section $(55 \mathrm{mg} / \mathrm{L})$ that surpassed water quality standard Class II. While the middle stream and downstream still met water quality standard Class II. The high TSS in the upstream could be caused by the watershed condition, which experienced erosion due to the deforestations.

\subsubsection{Dissolved oxygen (DO)}

Dissolved oxygen is required by all water living organism for breathing, metabolic processes, and the exchange of substances to produce energy for life, growth, breeding and development [8]. Dissolved oxygen plays an essential role in the survival of aquatic organisms. Still, it also plays a role in decomposing organic and inorganic materials through aerobic process by microorganisms in water. In waters, the primary source of oxygen comes from the air through diffusion and photosynthesis of aquatic vegetables [9]. Each organism required dissolved oxygen with different and relatively various levels depending on the type, stage, and activity [10].

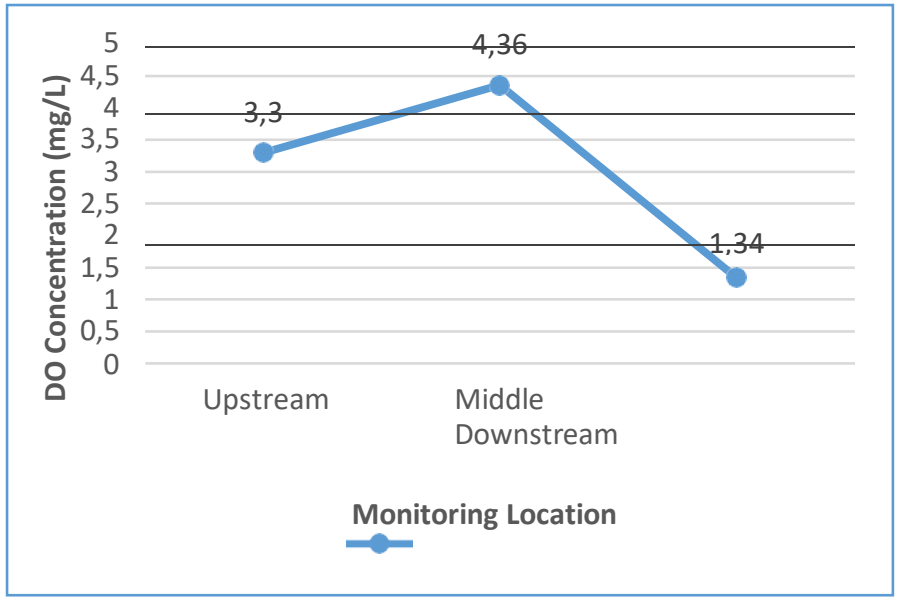


Fig. 2. Graph of DO concentration in the monitoring location

DO values that meet water quality standard class II were only in the middle area, while the DO value was less than $4 \mathrm{mg} / \mathrm{L}$ for upstream and downstream. The low DO value in Sani river water indicated the presence of a high number of microorganisms using oxygen to decompose organic matter.

\subsubsection{Biological Oxygen Demand (BOD)}

BOD is the amount of oxygen needed to carry out microbiological processes in the water. BOD describes the amount of organic material that can be decomposed biologically, and the intended organic material is fat, glucose, protein, esters, aldehydes, and so on [6]. BOD is a benchmark of waste pollution from water [11]. The greater the BOD value of waters indicates the high organic matter concentration in the waters [12]. Natural waters have BOD values between $0.5-7.0 \mathrm{mg} / \mathrm{L}$, while waters that have a BOD value of more than $10 \mathrm{mg} / \mathrm{L}$ are considered to have experienced pollution [6].

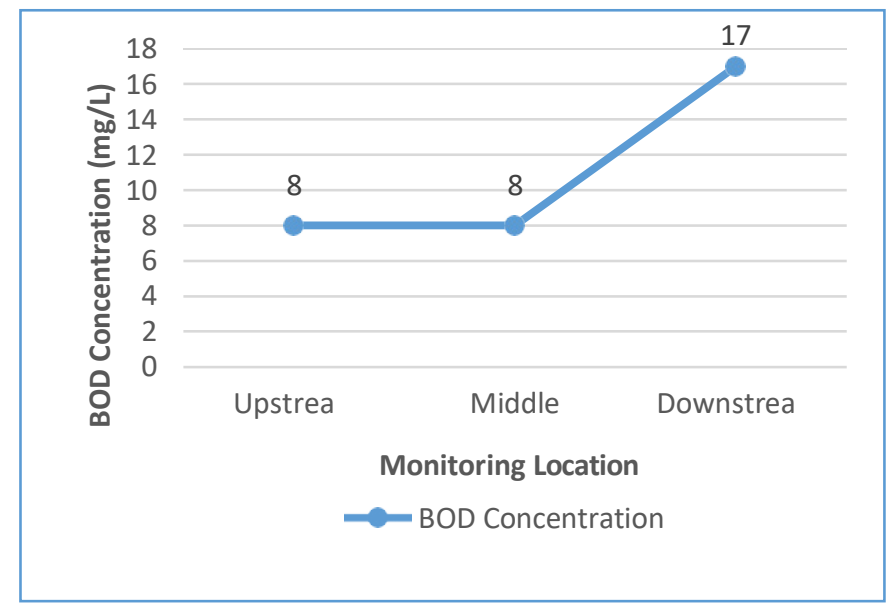

Fig. 3. Graph of BOD concentration in the monitoring location

Based on obtained data from the study area demonstrated that the BOD value washigher than $3 \mathrm{mg} / \mathrm{L}$, which means it surpassed the water quality standard Class II so. It implied that Sani river water shoul not have functioned for recreational facilities, freshwater fish farming, animal husbandry, and agriculture. The highest BOD value is in the downstream $(17 \mathrm{mg} / \mathrm{L})$ and is classified as more polluted than the middle and upstream sections. The highest amount of BOD in the downstream could be caused by restaurant activities, domestic waste from surrounding residents, and the accumulation of pollutant concentrations transported from the upstream and middle sections.

\subsubsection{Chemical Oxygen Demand (COD)}


COD (chemical oxygen demand) means the total amount of oxygen needed to chemically oxidize organic material, both those that can be degraded biologically or those that are difficult to be degraded biologically to $\mathrm{CO}_{2}$ and $\mathrm{H}_{2} \mathrm{O}$ [6]. The COD rate measures water pollution by total organic substances that can be chemically decomposed [13]. The water quality standard Class II for COD is $25 \mathrm{mg} / \mathrm{L}$. 


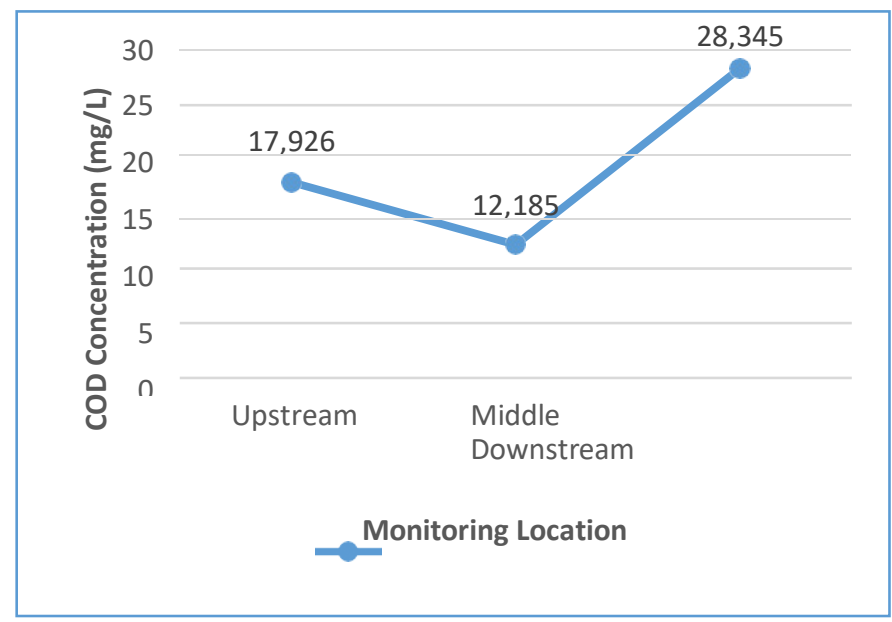

Fig. 4. Graph of COD concentration in the monitoring location

The COD analysis results demonstrated that the COD value exceeded the quality standard $(28,345 \mathrm{mg} / \mathrm{L})$. The cause can come from household activities, industry and workshop in urban areas, and the accumulation of pollutant concentrations.

\subsubsection{Fecal Coliform}

Fecal coliform is a member of coliform that can ferment lactose at $44.5^{\circ} \mathrm{C}$ and is the most dominant part $(97 \%)$ in human and animal feces [6]. Fecal coliform is a bacterium that is widely produced from a septic tank. The presence of bacteria in the waters indicates surface water quality and the suitability of the use of the water as drinking water, irrigation, recreation, or fisheries [14].

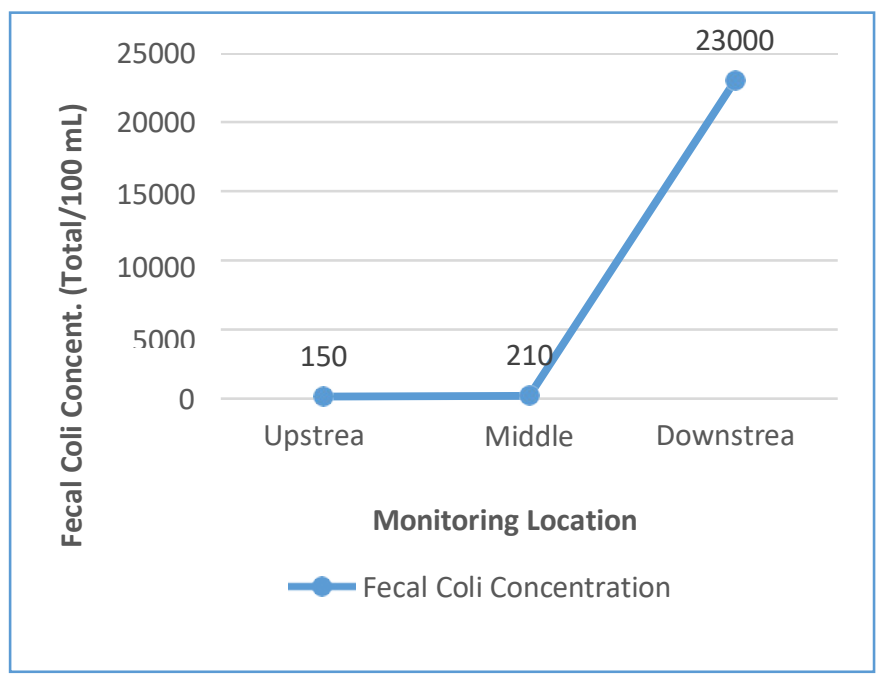

Fig. 5. Graph of Fecal Coliform concentration in the monitoring location

From the measurement data, it is known that the largest concentration of fecal coliform is in the downstream $(23,000 / 100 \mathrm{ml})$ while the water quality standard for class II is only 
$1000 / 100 \mathrm{ml}$. The high concentration of fecal coliform in the downstream area that passes through urban areas is caused by the population number in urban areas which is relatively more than the population in the upstream and middle areas.

\subsubsection{Total Coliform}

Total coliform is the total number or group of various types of bacteria contained in the environment. Total coliform can act as an indicator to detect the presence of pathogens in water [15]. The aquatic environment is easily polluted by pathogenic (harmful) microorganisms that enter from various sources such as settlements, agriculture, and animal husbandry. Bacteria commonly used as an indicator of water body contamination are bacteria classified as Escheria coli or coliform bacteria, which generally live in human and animal feces [6]. Total coliform bacteria consist of Escheria coli, Citrobacter, Klebsiella, and Enterobacter [6]. The value of total coliform is directly proportional to the level of pollution [15]. The presence of these bacteria can be used as an indicator in assessing the level of water hygiene.

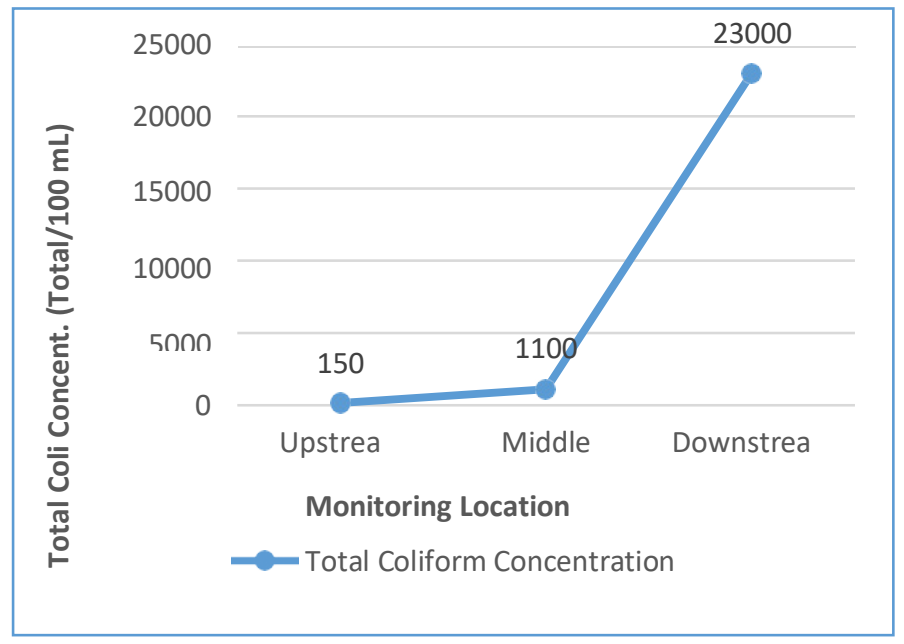

Fig. 6. Graph of Total Coliform concentration in the monitoring location

Like the condition with fecal coliform, the largest coliform concentration is in the downstream $(23,000 / 100 \mathrm{ml})$, while the water quality standard for class II is only $1000 / 100$ $\mathrm{ml}$. Elevated levels of total coliform in the downstream areas were due to the higher population in urban areas than the middle and upstream areas-the total accumulation of coliform occuring in the downstream as a result of transport from upstream to downstream.

\section{2 Water Quality Status Analysis}

Referring to the Guidelines for Determination of Water Quality Status from Minister of Environment (No. 115/2003), the water quality status is the water quality conditions that indicate polluted terms or right conditions at a water source within a specific time by comparing with the specified water quality standards. In this study, the parameters used to analyze water quality status were TSS, DO, BOD, COD, Fecal coliform, and total coliform. Water quality status analysis was performed using the Pollution Index (PI) method. The results of the calculations can be seen in the following table: 
Table 5. Pollution Index Calculation Result

\begin{tabular}{cccc}
\hline No. & $\begin{array}{c}\text { Monitorin } \\
\text { g }\end{array}$ & $\begin{array}{c}\text { Pollution } \\
\text { Index } \\
\text { Value }\end{array}$ & $\begin{array}{c}\text { Water Quality } \\
\text { Status }\end{array}$ \\
\hline 1 & Location & 2,28 & Slightly polluted \\
2 & Thstream & 2,27 & Slightly polluted \\
3 & Downstrea & 5,86 & Moderate polluted \\
& $\mathrm{m}$ & & \\
\hline
\end{tabular}

Based on the results of the Pollution Index (PI) value, it could be concluded that the Sani river water quality status from upstream to downstream has decreased from slightly to moderate polluted conditions. The quality of Sani river water did not meet the designation quality standards for water class II so that the Sani river water should not be applied as a means of water recreation, freshwater aquaculture, animal husbandry, and agriculture irrigation water.

\section{Conclusion}

From 3 study areas, the downstream has the lowest water quality status due to 5 parameters exceeded the water quality standards Class II, such as DO, BOD, COD, fecal coliform, and total coliform. The middle area owns the best water quality status because only one parameter surpassed the water quality Class II, i.e., BOD. Sani river water quality status inthe upstream and middle demonstrated slightly polluted conditions, while the downstream indicated moderate polluted.

\section{Suggestions}

Regular monitoring of the Sani River's water quality needs to be done at least twice a year in the rainy and dry seasons to find out the actual condition of the Sani river water. There are necessary efforts to control Sani river water condition to improve and maintain the quality of Sani river water remaining below water quality standard class II according to Government Regulation No. 82 of 2001. 


\section{References}

1 D. Ratnaningsih, R. P. Lestari, E. Nazir, and R. Fauzi, "Pengembangan Indeks Kualitas Air Sebagai Alternatif Penilaian Kualitas Air Sungai,” Ecolab, 12, 2, 53102,(2018).

2 M. B. et al Hoelman, "PANDUAN SDGs,” no. November, (2015).

3 R. G. E. Bhaskoro and T. Ramadhan, "Evaluasi Kinerja Instalasi Pengolahan Air Minum (IPAM) Karangpilang I PDAM Surya Sembada Kota Surabaya Secara Kuantitatif," J. Presipitasi Media Komun. dan Pengemb. Tek. Lingkung., 15, 2, 62$68,(2018)$.

4 Kementerian Lingkungan Hidup dan Kehutanan Republik Indonesia, "Indeks kualitas lingkungan hidup 2014 (English translation: Environmental Quality Index 2014)," (2014).

5 A. S. Suryani, "Persepsi Masyarakat Dalam Pemanfaatan Air Bersih ( Studi Kasus Masyarakat Pinggir Sungai Di Palembang )," Aspirasi, 7, 1, 33-48, (2016).

6 H. Effendi, Telaah Kualitas Air: Bagi Pengelolaan Sumber Daya dan Lingkungan Perairan. Yogyakarta: PT Kanisius, (2003).

7 Azwir, “Analisa Pencemaran Air Sungai Tapung Kiri Oleh Limbah Industri Kelapa Sawit PT. Peputra Masterindo Di Kabupaten Kampar," Universitas Diponegoro, (2006).

8 Pariwono, “Oksigen Terlarut (DO) Dan Kebutuhan Oksigen Biologi (BOD) Sebagai Salah Satu Indikator Untuk Menentukan Kualitas Perairan," Oseana, 30, 3, 21-26, (2005).

9 S. O. Ningrum, “Analisis Kualitas Badan Air Dan Kualitas Air Sumur Di Sekitar Pabrik Gula Rejo Agung Baru Kota Madiun,” J. Kesehat. Lingkung., 10, 1, 1-12, (2018).

10 W. A. Gemilang and G. Kusumah, "Status Indeks Pencemaran Perairan Kawasan Mangrove Berdasarkan Penilaian Fisika - Kimia Di Pesisir Kecamatan Brebes Jawa Tengah," EnviroScienteae, 13, 2, 171-180, (2017).

11 B. Hamuna, R. H. R. Tanjung, Suwito, H. K. Maury, and Alianto, "Kajian Kualitas Air Laut dan Indeks Pencemaran Berdasarkan Parameter Fisika-Kimia Di Perairan Distrik Depapre , Jayapura," J. Ilmu Lingkung., 16, 1, 35-43, (2018).

12 S. Yudo, "Kondisi Kualitas Air Sungai Ciliwung Di Wilayah DKI Jakarta Ditinjau Dari Parameter Organik, Amoniak, Fosfat, Deterjen dan Bakteri Coli," J. Akuakultur Indones., 6, 1, 34-42, (2010).

13 W. Wardhana, Dampak Pencemaran Lingkungan. Yogyakarta: Andi Offset, (2004).

14 D. A. Santy, S. Adyatma, and N. Huda, "Analisis Kandungan Bakteri Fecal Coliform pada Sungai Kuin Kota Banjarmasin,” Maj. Geogr. Indones., 31, 2, 51, (2017).

15 E. Yogafanny, "Pengaruh Aktifitas Warga di Sempadan Sungai terhadap Kualitas Air Sungai Winongo," J. Sains dan Teknol. Lingkung., 7, 1, 41-50, (2015). 